\title{
The overlooked public: examining citizens' perceptions of and perceived role in hosting mega-events
}

\author{
Kelly Vibber ${ }^{1}\left[\right.$ Alessandro Lovari $^{2}$
}

Revised: 16 February 2021 / Accepted: 6 March 2021 / Published online: 29 March 2021

(c) The Author(s), under exclusive licence to Springer Nature Limited 2021

\begin{abstract}
This research aims to answer questions about how citizens perceive the hosting of mega-events, how they view their role in interacting with foreign visitors (e.g., person-to-person diplomacy), and to what extent they communicate in support of, or against, their country's mega-event efforts. By focusing inward and examining citizen perceptions and communicative actions, this research expands the work that has been done around nation branding and the impact of hosting mega-events, which usually foregrounds the response of foreign publics. Internal/citizen publics are largely overlooked and bear great importance from a communication, public relations, and public diplomacy standpoint. A convenience sample of 426 Italian citizens completed the online survey. Results indicate that citizens who placed high importance on their interactions with foreigners reported significantly higher scores on attitudes toward Italy hosting the World Exposition (Expo), positive megaphoning behaviors about Italy hosting the Expo and perceived themselves as ambassadors during the mega-event. The findings highlight that the important role citizens can play as ambassadors, both of their country and on behalf of the megaevent. Their megaphoning behavior and perception of the importance of interacting with foreign visitors have the potential to magnify the positive impact of hosting mega-events both internally and abroad.
\end{abstract}

Keywords Citizen diplomacy $\cdot$ Megaphoning $\cdot$ Mega-events $\cdot$ Nation branding $\cdot$ Soft power

\section{Introduction}

A variety of scholars in public relations and public diplomacy have considered the role of mega-events and the impacts they have for hosting and participating countries (e.g., Kim et al. 2014; Muller 2015; Wang 2013). Megaevents can be defined as, "ambulatory occasions of a fixed duration that attract a large number of visitors, have a large mediated reach, come with large costs, and have large impacts on the built environment and the population" (Muller 2015, p. 634). Much of the related public relations and public diplomacy research focus primarily on the ways in which hosting mega-events (i.e., World Expos, World Cups,

Kelly Vibber

kvibber1@udayton.edu

Alessandro Lovari

alessandro.lovari@unica.it

1 Department of Communication, University of Dayton, Dayton, USA

2 Department of Political and Social Science, Università degli studi di Cagliari, Cagliari, Italy the Olympics) builds, improves, or expands the perception foreign and external publics have of the hosting country (Grix and Houlihan 2014; Wang 2013). Some explore the ways foreign countries present themselves to host countries (e.g., the Shanghai World Expo in 2010, Wang 2013). However, despite Muller's (2015) definition citing large impacts on the population of the host country, little scholarship examines citizens' perceptions of mega-events or their perceived roles related to them.

This gap is particularly important for scholars to address given three key ideas in public relations and public diplomacy literature. First, internal relationships and boundary spanning stakeholders (e.g., employees, citizens, expatriates, students) are important and often critical to developing positive external relationships and identities (Kim and Rhee 2011) for companies, organizations, and countries. Second, scholars from both fields advocate that person-to-person interaction between people from different countries has the ability to influence the perception and soft power of a country (Attias 2012; Melissen 2005; Yun 2012; Yun and Toth 2009). Third, the people of a country, from regular citizens to celebrities, are identified as one of the six components of 
a country's competitive identity, through which nations can build their soft power, reputation, and credibility (Anholt 2007, 2015).

In order to examine the perceptions and actions of citizens in a country hosting a mega-event, this paper focuses on the World Expo hosted in Milan, Italy from May to October 2015. This focus diverges from that of the majority of mega-event studies which tend to examine large sporting events such as the Olympics or the World Cup. In contrast, the World Expo occurs over a much longer time span and is often more accessible to both the hosting nation's citizens and foreign tourists.

This study aims to understand Italian citizens' perceptions of the Expo and mega-events overall, what communicative actions they engage in on behalf of (or against) their country hosting the Expo, how citizens view their interaction with foreigners, as well as if they perceive themselves as ambassadors of their nation in mega-event settings. By focusing on these areas, this work can begin to explore this topic from the citizens' perspective, complementing works that have examined citizens' roles either theoretically or from a government or system level perspective. The next section reviews the relevant literature on mega-events and citizen diplomacy. It highlights where this work begins to address the overlooked citizen public, as well as the implications for a nation's competitive identity and soft power.

\section{Literature review}

\section{Mega-events and the global arena}

Many scholars and practitioners have embraced the idea that mega-events pose a unique and substantial opportunity to develop and promote a nation's brand and competitive identity, as well as their soft power (Grix and Houlihan 2014; Kim et al. 2014; Wang 2013; Zhou et al. 2013). This is due in part to key outputs of mega-events like visitor attractiveness and mediated reach (Muller 2015). The increase in tourism both during and after a mega-event has potential for diplomatic and economic impacts. In hosting the 2018 Winter Olympic Games in Pyeongchang, \$39.8 billion of the predicted $\$ 59$ billion total in economic impact was driven by increased long-term tourist visitation (Kim et al. 2014). In addition, the increased global visibility from the media attention on mega-events can also magnify messages a nation wants to send. For instance, coverage of the London 2012 Olympics across all media platforms made the Olympics available to 4.8 billion people (Billings and Hardin 2013). Broadcasting the opening ceremonies provides the host nation with a global audience for storytelling about their nation, allowing them to tailor their narrative and highlight key themes. These themes are often repeated in coverage around the world, as was the case in U.S. and Chinese coverage of the London Opening Ceremonies (Zhou et al. 2013). In addition, the use of social media by megaevent organizers extends the reach of messages all across the globe. These messages are often reshared by digital publics on their accounts, thus, increasing the visibility of the topic in the contemporary communication ecologies.

Finally, the interaction between many countries over the course of the mega-event, both symbolically through sport or pavilions, as well as formally through visits by ambassadors, heads of state, etc., has important implications for public relations and diplomacy (Wang 2013). Thus, there are many tangible and intangible incentives to motivate a country to host mega-events. At the heart of the intangible incentives are the concepts of competitive identity, nation brand, and soft power.

\section{Competitive identity, nation brand(ing) and soft power}

Nation branding is a specific subset of place branding. The terms "nation branding" and "nation brands" were introduced in popular and academic discourse in the mid-1990s (Wang 2013, p. 7, footnote 21). Anholt (2007) wrote about a nation brand as something more akin to reputation or image, a factor that would guide and impact that nation's growth and be influential in attracting others to them. Nation branding instead "refers to the application of branding principles and practices to a country's communication efforts to shape international perception and understanding" (Wang 2013, p. 8).

Disapproving of the somewhat commercial approach applied to the concept of nation branding, Anholt developed the concept of competitive identity to consider, "how the nation as a whole engages, presents and represents itself to other nations..." (Anholt 2015, p. 191, italics original). Competitive identity is composed of six elements: the country's promotion as a tourist destination, along with the firsthand experiences of people who visit the country; the brands the country exports; the government's policies; the business climate; the country's cultural products; and the people of the country, including both celebrities and ordinary people (Anholt 2007). The first and last of these have particular relevance for mega-event experiences of both foreigners and residents, as well as citizen or person-to-person (P2P) diplomacy, which will be discussed in a following section. The third and the fifth elements overlap with components of soft power, the development of which often motivates hosting a mega-event.

Nye (2008a) introduced the concept of soft power in 1989 , defining it as a country's ability to achieve its goals through appeal or attractiveness to others as opposed to through coercion or payment (Nye 2004). According to 
Nye (2008b), soft power derives from three main sources: a country's "culture (in places where it is attractive to others), its political values (when it lives up to them at home and abroad), and its foreign policies (when they are seen as legitimate and having moral authority)" (p. x). Nye's conceptualization of sources of soft power heavily emphasizes the parentheticals above and focuses primarily on government and nation state (macro-level) sources of soft power.

Other scholars from public relations and public diplomacy have examined the role that corporations, organizations, and even individuals can play in public diplomacy and building or damaging a nation's soft power (Attias 2012; Melissen 2005; Payne 2009; Zaharna 2005). Nye (2004) has also spoken about the relevance of cultural and educational exchanges to influence soft power, thus, acknowledging the role of actors other than the government. It is at the intersection of these three things: culture, promotion of attractive values or policies, and the facilitation of opportunities for several actors to engage with foreign publics, that megaevents possess great potential for affecting a nation's competitive identity, brand, and soft power.

\section{Mega-events: costs and legacy}

The historical and present connections between megaevents and diplomacy are well documented, particularly in the realm of sport and diplomacy (e.g., Dubinsky 2019; Murray and Pigman 2014). Despite the generally optimistic outlook on possible outcomes of hosting a mega-event, there are also very real costs and important considerations. Mueller (2015) cites financial cost and urban transformation as major points of investment for a hosting nation, since these events require substantial structural support (e.g., stadiums, pavilions, housing for athletes or volunteers, additional tourist accommodations). The need for structures often not only results in area-based urban renewal (Deng et al. 2016) as in the case of Shanghai's Expo 2010 but may also involve construction around the country (e.g., Brazil's 2014 World Cup). Even with sizeable investment by the host country, positive outcomes are not guaranteed. Several studies have reported a mixed impact on the country's image, both overall and as a destination (Heslop et al. 2009; Kim et al. 2014), making it even more difficult to advocate the investment to a nation's citizenry.

Consider Brazil's 2014 World Cup as an example of cost and infrastructure investment involved. Twelve cities served as venues for the event, which had an estimated cost over $\$ 11$ billion (Koba 2014). Of that, $\$ 3.5$ billion was used to build six stadiums and refurbish another six for the tournament. The high cost of the event, supported by taxpayer money, led to charges of corruption and expressed opposition to spending money on these efforts instead of addressing local infrastructure and housing (Koba 2014). Additionally, the stress of living through chaotic conditions generally associated with construction at this scale may further taint the citizenry's attitudes toward the event and the government.

It is important to examine the citizen public further because they are a key stakeholder in hosting mega-events. Citizens are often the ones directly impacted by the financial and logistical needs of these events. They also function as the face of the hosting nation to the many visitors during the event. Despite these factors, little work has examined the citizens' perception of the mega-events and their relationship to, or role in them.

\section{Citizen involvement in mega-events and building soft power}

Although there is limited work that focuses specifically on citizens' perception of and role in mega-events, there is growing interest in residents' perceptions of and experiences with these events (Chalip and Fairley 2019). The research that does exist is found mainly in tourism, place branding, sports, and public affairs scholarship (e.g., Braun et al. 2013; Casias and Montiero 2019; Heslop et al. 2009; Murray and Pigman 2014; Pappas 2014; Ye et al. 2012). These studies provide an initial context for viewing citizen involvement in mega-events and highlight the need for more work focusing on the citizens' perspective, involvement, and diplomatic potential through communicative actions.

\section{Citizen involvement in mega-events}

Pappas (2014) framed the importance and the overlooked nature of citizens' role in mega-events stating, "Mega-event successes depend considerably on the host community's support, even if [mega-events] planning and development allows little input from local residents" (p. 10). Multiple studies have highlighted the role of this support by examining citizen involvement or community participation in some stage of the mega-event hosting process (Lamberti et al. 2011; Pappas 2014; Wang 2014). These studies come to mixed conclusions. Pappas (2014) found that while community participation on tourism issues related to the London 2012 Olympics did not have a strong direct influence on community support of the Olympics, it did more strongly affect the perceived positive and negative effects of hosting the Olympics, which indirectly influenced community support.

Similarly, efforts to promote citizen involvement in the 2010 Shanghai World Expo through specific social projects also achieved mixed effects (Wang 2014). While they were largely successful at gaining involvement, the citizens' perceived value of that involvement varied. In some situations, the role for citizens was quite passive and restricted to lowerlevel governance issues. In other cases, the involvement was perceived as tokenism. However, there were indications of 
responsiveness to citizen concerns. Strong negative opinions and protests by the citizens were able to achieve modifications in the approach the government took to projects and community involvement (Wang 2014).

Focusing on event organizers' perception of citizen involvement, Herezeniak and Florek (2018) interviewed five high-level members of Expo teams in five European countries. Their study concluded that all participants viewed citizen involvement during the event as important. However, there were mixed opinions on involving citizens before the event. Participant comments reflected the following divergent views: involvement early should be limited to the most interested publics, involvement was not necessary because the application to host was a political one, and citizen involvement early in the process is important now but was not when they had hosted an Expo. In terms of the significance of citizen involvement, the participants acknowledged "citizens as creators and carriers of a city's atmosphere, promoters of the Expo, commentators and reviewers of the activities around the Expo and service providers (e.g. of city tours)" (Herezeniak and Florek 2018, p. 96).

\section{Citizen perception of mega-events}

A second set of mega-event studies that emphasized citizens, focused instead on their perceptions of and attitudes toward mega-events (e.g., Heslop et al. 2009; Preuss and Solberg 2007). In examining the data across 117 polls, Preuss and Solberg (2007) found that the majority of citizens, three out of four, supported hosting large sporting events and that this positivity was stronger in low-income nations. That said, publics in countries with a public sector deficit were more skeptical of hosting events.

In addition, differences between expectations of hosting a mega-event and actual experience were also found to impact citizen perception. A study of residents' attitudes toward the 2010 Shanghai World Expo before and during the Expo revealed that residents in the higher supporting attitude cluster perceived fewer negative impacts of the Expo (Ye et al. 2012). Interestingly, the before and during-Expo surveys revealed significant differences in responses on nine items. In some cases, their pre-Expo beliefs in negative outcomes (e.g., higher levels of crime) were significantly lower in the during-Expo Survey, and anticipated positive outcomes (e.g., promoting Shanghai as a tourist destination) were significantly higher, both showing positive change in perception. In other cases, some positive pre-Expo hopes (e.g., personal/family benefits in terms of culture and communication) were significantly lower in during-Expo surveys, indicating negative change in perception (Ye et al. 2012). Similarly, a study by Heslop et al. (2009) of Chinese citizen perceptions before and after the Beijing Olympics found that they were overwhelming lower after the Olympics, despite the Games being successful overall. While Chinese views on the several items evaluating the Olympic Games, the country and people of China, and China as a destination were more positive than the American comparison group, they were still lower on nearly all items after the event than they before. Heslop et al. (2009) acknowledged various factors could have impacted this shift including Chinese disappointment of hopes for new freedoms/political freedoms, several major failures of the Chinese production system around the time of the Games and "the general malaise which can follow the culmination of any major project, regardless of its success..." (p. 426).

Taken as a whole these studies highlight several key findings. First, citizen support for mega-events may vary by event type and financial condition of the country. Second, significant changes may occur in citizens' perceptions of/ attitudes toward mega-events and their potential outcomes during the lifespan of the event. Third, community participation in topics related to the mega-event (e.g., tourism, transportation) seems to be related to their perceptions of the effects of hosting mega-events, as well as indirectly related to support for the mega-event overall. That said it is possible that citizen engagement may also lead to citizen outrage if they are not consulted in earnest. Last, organizers clearly value citizen involvement and see its importance for a successful event. However, they differ on when that involvement should begin and what it should look like. To begin to understand the context of Italian citizens' perceptions of mega-events in general and Italy's Expo Milano specifically, this study posed the following research questions:

\section{RQ 1 How do Italian citizens view mega-events?}

RQ 2 What are Italian citizens' perceptions of Expo Milano?

\section{Citizen diplomacy, person-to-person diplomacy, and soft power}

Despite the acknowledgement of the importance of citizens' support for the success of mega-events, one of the major oversights of the studies reviewed above is their failure to consider citizen interaction with foreign visitors during these mega-events. The perceived potential role of citizens in public diplomacy has grown considerably over the past two decades. Diplomacy was originally perceived as only being enacted at the level of nation states. However, the rise of public diplomacy, diplomatic efforts that focused on a nation state's communication with foreign citizens instead of their heads of State, increased the significance of the citizens. Yun and Toth (2009) posited that in an ever-globalizing world where communication and travel across borders were becoming more frequent, interactions between citizens of different 
countries (person-to-person diplomacy) would become driving forces in publics' perceptions of and attitudes toward other nations, in turn impacting a nation's soft power. This concept of individuals or publics having diplomatic consequences on each other through interaction is present in public diplomacy scholarship as citizen diplomacy (Attias 2012) and may occur organically or through formalized interactions and structures.

Anholt's (2007) concept of competitive identity as well as Nye's (2011) work on the future of power both highlight the influence of citizens' and their interaction with foreigners on key intangible national assets (e.g., competitive identity and soft power). The influence of these interactions has expanded potential when hosting a megaevent since thousands of foreigners visit and most of their encounters are likely to be with everyday citizens of the host country. While there is substantial scholarly discussion on citizens' importance to public diplomacy, there is limited research that examines the citizens' awareness of their influence. Thus, the following research questions were asked.

RQ 3 How do Italian citizens view the importance of interacting with foreigners?

RQ 4 How is the level of importance they place on interacting with foreigners related to how they actually respond to the potential of interacting with foreigners at the Expo?

In the context of this study, citizens who see their, and other Italians', interactions with foreigners as important for representing Italy and in turn for foreigners' perceptions of Italy, can be presumed to have more positive attitudes towards situations that facilitate this interaction. They are also, likely to perceive themselves as taking on a more specific role during mega-events. Work from Braun et al. (2013) and Herezniak and Florek (2018) has found support for the role of citizens as ambassadors in place branding or mega-events, though neither directly surveyed citizens on their perception of this role. Thus, the following hypotheses were posited:

H1 Individuals who place high levels of importance on interacting with foreigners will report more positive perceptions of mega-events, than those who do not.

H2 Individuals who place high levels of importance on interacting with foreigners will report more positive perceptions of Expo Milano, than those who do not.

H3 Individuals who place high levels of importance on interacting with foreigners will report stronger feelings of perceived ambassadorship, than those who do not.

\section{Megaphoning}

Megaphoning is defined as the voluntary proactive information transmission by members of a public about their direct experiences (e.g., with an organization or country) to those without a direct experience (cf. micro-boundary spanning, Kim and Rhee 2011). Citizens who interact with foreigners are important to a nation's soft power and brand because the citizens are able to act as boundary spanning publics, providing a connection between their home country and the foreigners. Citizens represent an "insider" group, much like employees do for corporations. They have a different and deeper understanding of their country than those visiting and this places them in a unique position to engage in megaphoning (Vibber and Kim 2015, 2019).

In this study, Italian citizens who have directly experienced the Expo could also megaphone to individuals who have not, whether they are foreign or domestic. Citizens can activate in order to collaborate with the local initiatives, or they can mobilize to protest against the forthcoming megaevents. Those who place a high importance on interacting with foreigners are likely to support events that may facilitate this interaction. Therefore, they are likely to engage in communicative action (megaphoning) in support of these events, to a variety of audiences (e.g., friends, family, and the general public). Thus, the hypotheses were posited.

H4 Individuals who place high levels of importance on interacting with foreigners will report higher positive megaphoning scores about Italy hosting the Expo, than those who do not.

H5 Individuals who place high levels of importance on interacting with foreigners will report lower negative megaphoning scores about Italy hosting the Expo, than those who do not.

\section{Context: Expo Milano 2015}

Expo Milano 2015, the World Expo hosted in Milan, Italy from May 1 to October 31, 2015 provides the context for this study. The World Expo, also known as the World Exposition, World's Fair, or International Exhibition, has a history reaching back to the middle of the 1800 s, making it a wellestablished global mega-event. Over the years, it has been a platform for highlighting major industrial and technical inventions, an arena for cultural exchange, and a venue for nation branding, state diplomacy, and public diplomacy.

The Expo Milan 2015, dedicated to the topic "Feeding the Planet. Energy for Life," was a great success in terms of participation. According to the official report, $21 \mathrm{mil}-$ lion people visited the pavilions, $1 / 3$ of which were foreign 
visitors and 2 million of which were students. The average daily participation over the six months was 110,000 people. In terms of public diplomacy, 250 foreign delegations visited the exhibition, including 35 nations' presidents and 25 heads of government. Expo Milan cost 3271 billion Euro with 1252 billion in public contributions. According to the Official Expo Report published in 2018, the provisional budget was fully respected, and the organizers were able to reduce the total expenditures by $6 \%$ without decreasing the quality of the mega-event (Expo $2015 \mathrm{Spa}$, 2018). In terms of professional media, Expo Milan was visited by 28,221 journalists, including 7183 foreign journalists, and the official media coverage reported included 13,564 radio and television services, 148,000 articles in Italian newspapers, and 38,000 online news items.

Besides being the most recently held World Exposition, the Expo Milano provides an interesting study context for many reasons. First, it is the fact that Italy has hosted a variety of mega-events over the last century (e.g., 1934 and 1990 FIFA World Cup, 2006 Turin Olympics) making it an interesting nation to focus on because the citizens hold a concept of hosting mega-events and their impact in recent memory. Second, is the large number of countries taking part in the exhibition. The organizing committee of Expo 2015 Milan announced the official participation of 141 nation-based exhibitors, 137 countries including Italy and four international organizations: the United Nations, the European Union, the Pacific Islands Forum, and the Caribbean Community (Expo 2015 Spa, 2018).

Third, there were a variety of conflicts, concerns, and protests around the hosting of the Expo, indicating a lack of universal citizen support for the endeavor (Massidda and Parisi 2016, 2017). Major concerns included globalization issues, political corruption, bribery, and sustainability. In addition, seven managers and ex-members of the Italian parliament were arrested in May 2014 over "alleged attempts to influence public tenders for Milan's Expo" (Parodi 2014, para 1).

Fourth, the length of the Expo, six months, is substantial, especially compared with other mega-events that often run for only a few weeks or a month (e.g., the Olympics or the World Cup). This extended period allowed the citizens longer to develop clearer ideas about and attitudes toward the mega-event, its outcomes, and their role in it.

Finally, Expo Milano was the first "social exhibition" where social media played a relevant role in communicating the mega-event. This was true both from an organizational point of view, through the use of official social media channels and "social media days" with thousands of bloggers and digital influencers, as well as from the citizens' point of view with online publics posting and sharing messages, videos, and photos about the event. Global social media of Expo Milan reached 300 million people in twenty digital platforms, through the creation of bottom-up unofficial pages and groups of users who helped visitors find information about the exhibition (Expo 2015 Spa, 2018).

\section{Methods}

To investigate the research questions and hypotheses, authors administered an online survey (Vehovar and Manfreda 2008). Participants for the study were recruited via Facebook, the platform where the majority of Expo related conversations took place on the web. In particular, researchers collaborated with the group "Expo 2105 Milano Consigli per gli utenti (English translation: Expo 2015 Milan Advice for users)," recognized as one of the most active unofficial Facebook pages about the Expo (Expo 2015 Spa, 2018), asking the group's administrators to share the survey to their members. Administrators posted several messages on the timeline inviting their members to participate in the survey. However, participants did not receive compensation for their participation. The group page did not advocate positive or negative stances about Expo Milan. Indeed, the group which had more than 25,000 members at the time of the study, defined itself as "not linked to the official website or EXPO 2015 organization; completely independent and with the only aim to offer a space for dialogue and information for those who have visited EXPO 2015" (translated to English by the authors).

Responses were collected for one month from February 24, 2016 until March 23, 2016.

The data were collected after the Expo had closed, and the first announcements regarding the outcomes were made and reported in the national media. The timing of the data collection was intentional. The announcement of outcomes brought the topic of the Expo back to the forefront of citizens' minds after they had time to solidify their opinions about the experience, and also provided concrete information that could clarify rumors or misconceptions about the outcomes of the Expo. A total of 426 Italian citizens completed the survey, with 315 women (73.9\%) and 111 men (26.1\%) making up the sample. The complete demographics of the sample are summarized in Table 1 . The survey was administered in Italian, with the measures being translated to Italian by one of the researchers, a native speaker of Italian.

\section{Measures}

All closed items were measured on a 1-to-7, strongly disagree to strongly agree Likert-type scale. The items used to measure the positive and negative megaphoning were adapted from Kim and Rhee's (2011) original scales. These items were modified to reflect the context, focusing on their communication about Italy hosting the Expo in Milan. Three items were used to assess negative megaphoning $(\alpha=0.821)$, 
Table 1 Demographic and Summary Information of Participants

\begin{tabular}{|c|c|c|c|c|c|}
\hline Gender & $N$ & $\%$ & Number of pavilions visited & $N$ & $\%$ \\
\hline Male & 111 & 26.1 & $1-5$ & 21 & 4.9 \\
\hline \multirow[t]{2}{*}{ Female } & 315 & 73.9 & $6-10$ & 43 & 10.1 \\
\hline & & & $11-15$ & 45 & 10.6 \\
\hline Age & & & $16-20$ & 39 & 9.2 \\
\hline $19-24$ & 45 & 10.6 & $21-25$ & 35 & 8.2 \\
\hline $25-29$ & 45 & 10.6 & $26-30$ & 45 & 10.6 \\
\hline $30-34$ & 48 & 11.3 & $31-40$ & 34 & 8.0 \\
\hline $35-39$ & 59 & 13.8 & $41-50$ & 38 & 8.9 \\
\hline $40-44$ & 67 & 15.7 & More than 50 & 126 & 29.6 \\
\hline $45-49$ & 50 & 11.7 & & 426 & 100 \\
\hline $50-54$ & 48 & 11.3 & & & \\
\hline $55-59$ & 28 & 6.6 & Education & $N$ & $\%$ \\
\hline $60-64$ & 23 & 5.4 & Elementary/middle school & 25 & 5.9 \\
\hline $65-70$ & 11 & 2.6 & High school & 199 & 46.7 \\
\hline \multirow[t]{2}{*}{ Over 70} & 2 & 0.5 & 3 year degree & 55 & 12.9 \\
\hline & & & Magistrate degree & 105 & 24.6 \\
\hline Place of residence & & & Master's degree & 30 & 7.0 \\
\hline Milan & 102 & 23.9 & Ph.D & 8 & 1.9 \\
\hline Northern Italy & 244 & 57.3 & Other & 4 & 0.9 \\
\hline Central Italy & 55 & 12.9 & & & \\
\hline Southern Italy & 13 & 3.1 & & & \\
\hline Islands (Sardinia, Sicily) & 9 & 2.1 & & & \\
\hline Outside of Italy & 2 & 0.5 & Expo volunteer & $N$ & $\%$ \\
\hline \multirow[t]{2}{*}{ Other } & 1 & 0.2 & Yes & 14 & 3.3 \\
\hline & & & No & 412 & 96.7 \\
\hline \multicolumn{6}{|l|}{ Employment } \\
\hline Student & 50 & 11.7 & Facebook group member & $N$ & $\%$ \\
\hline Private Sector & 162 & 38.0 & Yes & 355 & 83.3 \\
\hline Public Sector & 56 & 13.1 & No & 71 & 16.7 \\
\hline Business Owner & 12 & 2.8 & & & \\
\hline Freelance/Consultant & 68 & 16.0 & & & \\
\hline Retired & 24 & 5.6 & & & \\
\hline Unemployed & 36 & 8.5 & & & \\
\hline Other & 18 & 4.2 & & & \\
\hline
\end{tabular}

and four items were used to assess positive megaphoning ( $\alpha=0.827)$. Two items were used to measure the participants attitudes toward hosting mega-events $(\alpha=0.863)$. One item measured whether or not the participants "felt like an ambassador for Italy during the Expo." Three items gathered information related to participants' perceptions of interaction with foreigners at the Expo.

To measure attitudes toward the Expo, a four-item scale was created ( $\alpha=0.951)$. Exploratory factor analysis was conducted on these four items to check for unidimensionality. A single-factor solution was obtained with EFA using principal component analysis, with an eigenvalue of 3.51. To confirm this one factor solution, a confirmatory factor analysis was conducted and was found to have good fit $\left(\chi^{2}(2)=13.88, p=0.001\right.$; CFI $=0.994$, TLI $=0.982$, $\mathrm{SRMR}=0.01)$. A similar procedure was used to test and confirm the reliability of the four items developed to measure the importance of interacting with foreigners ( $\alpha=0.866)$. For this variable too, EFA using PCA reported a single-factor solution with an eigenvalue of 2.92. Confirmatory factor analysis successfully confirmed the single-factor solution $\left(\chi^{2}(2)=20.07, p<0.001\right.$; CFI $=0.983$, $\mathrm{TLI}=0.948, \mathrm{SRMR}=0.024)$. The survey items are listed in Table 2. In addition, a final open-ended question invited participants to share anything else they wanted about their experience or opinion of Expo Milano. 
Table 2 Measures, reliability estimates, means, and standard deviations for tested variables

\begin{tabular}{|c|c|c|c|c|c|c|}
\hline Variables & Items & $\begin{array}{l}\text { Number } \\
\text { of items }\end{array}$ & Cronbach's alpha & Alpha if deleted & Mean & $\begin{array}{l}\text { Standard } \\
\text { deviation }\end{array}$ \\
\hline \multirow[t]{4}{*}{ Perceptions of Expo Milano } & $\begin{array}{l}\text { Expo Milano has positively contributed to } \\
\text { foreigners' perception of Italy }\end{array}$ & 4 & 0.951 & 0.932 & 5.81 & 1.38 \\
\hline & Expo Milano has positively represented Italy & & & 0.924 & & \\
\hline & $\begin{array}{l}\text { Hosting the Expo has been good for Italy's } \\
\text { reputation }\end{array}$ & & & 0.926 & & \\
\hline & $\begin{array}{l}\text { Hosting the Expo has been good for the } \\
\text { economy of Italy }\end{array}$ & & & 0.961 & & \\
\hline \multirow[t]{3}{*}{ Negative Megaphoning } & $\begin{array}{l}\text { During the Expo I said negative things about } \\
\text { Italy hosting the Expo online and/or offline }\end{array}$ & 3 & 0.821 & 0.81 & 2.3 & 1.44 \\
\hline & $\begin{array}{l}\text { I have talked to people about the problems of } \\
\text { hosting the Expo }\end{array}$ & & & 0.685 & & \\
\hline & $\begin{array}{l}\text { I have talked about the mistakes and problems } \\
\text { of Italy's management of the Expo with family } \\
\text { and friends online/offline }\end{array}$ & & & 0.751 & & \\
\hline \multirow[t]{4}{*}{ Positive Megaphoning } & $\begin{array}{l}\text { I have made positive comments about Italy host- } \\
\text { ing the Expo online and/or offline }\end{array}$ & 4 & 0.827 & 0.757 & 6.05 & 1.14 \\
\hline & $\begin{array}{l}\text { I have attempted to change people's negative } \\
\text { opinions about the Italy hosting the Expo in } \\
\text { daily conversations online and/or offline }\end{array}$ & & & 0.759 & & \\
\hline & $\begin{array}{l}\text { I have refuted prejudiced or stereotyped opin- } \\
\text { ions about Italy hosting the Expo }\end{array}$ & & & 0.819 & & \\
\hline & $\begin{array}{l}\text { I recommended visiting the Expo to others, dur- } \\
\text { ing the Expo }\end{array}$ & & & 0.784 & & \\
\hline \multirow[t]{2}{*}{ Perceptions of Mega-events } & $\begin{array}{l}\text { Countries should be proud of hosting events like } \\
\text { the Expo or Olympics }\end{array}$ & 2 & 0.863 & 0.761 & 5.99 & 1.36 \\
\hline & $\begin{array}{l}\text { Hosting mega-events like the Expo help to build } \\
\text { the reputation and brand of the country }\end{array}$ & & & 0.761 & & \\
\hline \multirow[t]{4}{*}{$\begin{array}{l}\text { Importance of interaction } \\
\text { with Foreigners }\end{array}$} & $\begin{array}{l}\text { I think it is important for Italians to interact with } \\
\text { foreign visitors in order to represent Italy }\end{array}$ & 4 & 0.866 & 0.808 & 5.66 & 1.25 \\
\hline & $\begin{array}{l}\text { It is important for me to interact with foreigners } \\
\text { to represent Italy }\end{array}$ & & & 0.776 & & \\
\hline & $\begin{array}{l}\text { It is important for foreigner visitors to have } \\
\text { conversations with real Italians while they are } \\
\text { visiting so they will have a better understand- } \\
\text { ing of our culture and country }\end{array}$ & & & 0.816 & & \\
\hline & $\begin{array}{l}\text { I believe in representing Italy for foreigners } \\
\text { traveling here }\end{array}$ & & & 0.910 & & \\
\hline Ambassadorship & $\begin{array}{l}\text { I felt like an ambassador for Italy during the } \\
\text { Expo }\end{array}$ & 1 & & & 4.64 & 1.96 \\
\hline
\end{tabular}

\section{Data analysis}

Independent sample $t$ tests were used to test the hypotheses. To devise the two groups, the researchers segmented participants based on high and low perceived importance of interacting with foreigners. A composite variable for importance of interacting with foreigners was made by averaging the scores across all four items. Then, in order to ensure that the high group reflected a strong to very strong perception participants with a 6 and above, thus 6 and 7, were assigned a 1 . Those scoring a 5 or below made up the importance group and were assigned a 0 . Of the 426 respondents, 224 were assigned to the high-importance category and 202 were assigned to the low-importance category. The hypotheses were analyzed using SPSS version 24 .

\section{Results}

Research questions 1-4 were evaluated by assessing the mean score on the composite variables for each variable of interest. RQ 1 asked how Italian citizens view mega-events. The mean response for all respondents on a 7-point Likert scale was 5.99. Falling within the slightly agree to agree 
range, responses indicated that they generally felt countries should be proud of hosting mega-events and that these events help build the reputation and brand of the hosting country. RQ 2 examined Italian citizens' perceptions of the Expo Milano. The mean response for all respondents on a 7-point Likert scale was 5.81. Responses indicated that on average, they slightly agreed to agreed that the Expo had positively represented Italy, been good for Italy's reputation and economy, as well as positively contributed to foreigners' perceptions of Italy.

Several respondents also noted in the open response question that they were not only proud of hosting the World Expo, but also proud to be Italian, and to be citizens of Milan, the city that hosted such prestigious and important event.

RQ 3 asked how Italian citizens perceive the importance of interacting with foreigners.

The mean response for all respondents on a 7-point Likert scale was 5.67. Responses overall indicated a moderate level of agreement on the importance of themselves and Italians as a whole interacting with foreigners to represent Italy, as well as on the interactions' influence on foreigners' perceptions of Italy. Finally, RQ 4 asked how the level of importance Italians placed on interacting with foreigners related to how they actually respond to the potential of interacting with foreigners at the Expo. To answer this RQ, independent sample t tests were used to examine if the groups that placed either high or low importance on interacting with foreigners differed on these items. Results showed that the high-importance group reported significantly higher scores on the "opportunity to talk with people from other countries" at the Expo $(t=-11.97, p<0.001)$; the importance they placed on meeting people from other countries at the Expo $(t=-13.18, p<0.001)$; and meeting people from other countries being one of the motivations for attending the Expo $(t=-12.33, p<0.001)$.

All the hypotheses for the study predicted a difference in responses on variables of interest between the groups of respondents that placed either high or low importance on interacting with foreigners. The first two hypotheses focused on the respondents' perceptions of hosting mega-events generally (H1) and Italy hosting the Expo specifically (H2). They predicted that respondents in the high-importance group would report more positive scores than those in the low-importance group. Both H1 $(t=-7.32, p<0.001)$ and $\mathrm{H} 2(t=-9.25, p<0.001)$ were supported. In line with the basic tenants of person-to-person diplomacy, H3 predicted that respondents in the high-importance group would report higher scores than those in the low-importance group, on perceiving themselves as ambassadors during the Expo. This hypothesis was also supported $(t=-14.55, p<0.001)$.

Hypotheses 4 and 5 focused on the difference in megaphoning between groups. $\mathrm{H} 4$ predicted that those in the high-importance group would report higher scores on positive megaphoning than those in the low-importance group. Consequently, H5 predicted that those in the high-importance group would report lower scores on negative megaphoning than those in the low group. Both hypotheses were supported (H4; $t=-8.13, p<0.001 ; \mathrm{H} 5 ; t=2.60, p=0.01$; see Table 3).

\section{Discussion}

Results show that citizens who placed high importance on their interactions with foreigners reported significantly more positive attitudes toward Italy hosting the World Exposition, higher scores on positive megaphoning behaviors about Italy hosting the Expo, higher scores on embracing interaction at or being motivated to attend the Expo based on the potential to interact with foreigners, and perceived themselves as ambassadors during the Expo. They also reported significantly lower levels of negative megaphoning. Key contributions and implications of this study are discussed in the following sections.

\section{Examining citizen diplomacy in an overlooked and relevant context}

This study is one of few utilizing public relations and public diplomacy perspectives to directly inquire of citizens about their perspectives, communicative actions, and potential

Table $3 t$-Tests for hypotheses

\begin{tabular}{llllll}
\hline Variables & Hypothesis & $\begin{array}{l}\text { Low Interaction } \\
\text { Importance }\end{array}$ & $\begin{array}{l}\text { High Interaction } \\
\text { Importance }\end{array}$ & $t$ value & Significance \\
\hline $\begin{array}{l}\text { Attitude toward hosting } \\
\text { mega-events }\end{array}$ & $\mathrm{H} 1^{* *}$ & 5.50 & 6.43 & -7.32 & $p<0.001$ \\
$\begin{array}{l}\text { Attitude toward Expo } \\
\text { Ambassadorship }\end{array}$ & $\mathrm{H} 2^{* *}$ & 5.21 & 6.35 & -9.25 & $p<0.001$ \\
Positive megaphoning & $\mathrm{H} 3^{* *}$ & 3.45 & 5.71 & -14.55 & $p<0.001$ \\
Negative megaphoning & $\mathrm{H} 5$ & 5.60 & 6.45 & -8.13 & $p<0.001$ \\
\hline
\end{tabular}

$* * p<0.001$ 
diplomatic role as citizens in countries hosting mega-events. While many public relations scholars have acknowledged the role of citizen diplomacy in a variety of contexts, such as cultural or educational exchanges (Yun 2012; Yun and Toth 2009; Yun and Vibber 2012) and diaspora diplomacy (Bravo 2015), this work often emphasizes the perspective of the foreigner in the host country over that of the citizen's potential role. In addition, this research focused on citizens' diplomatic role in scholarship on mega-events, specifically non-sport mega-events like the World Expo, which has rarely been taken on from a public relations and public diplomacy perspective.

\section{Assessing citizens' awareness of P2P diplomacy and perceptions of their role}

A second major contribution of this study is that it examined citizens' own perceived importance of their interactions with foreigners as a direct representation of Italy and as a factor that could influence foreigners' perceptions of Italy. While research and studies prefacing the importance of person-to-person (P2P) diplomacy for competitive identity and soft power are abundant (e.g., Anholt 2007; Yun 2012), and some scholars have acknowledged the role of citizens as ambassadors for place branding (e.g., Braun et al. 2013; Herezniak and Florek 2018), the authors are not aware of studies that directly ask the respondents about their perceptions of the significance or impact of these every day actions during mega-events. This study not only found evidence that some citizens do place a high importance on these actions and have an awareness of their potential outcomes, but also that those who score high on this variable score significantly higher on self-perceptions of ambassadorship and attitudes of support for mega-events overall, as well as Expo Milan specifically.

\section{Practical implications}

These findings indicate that although some citizens inherently seem to grasp the importance of such interaction, it may be advisable for nation states to construct internal campaigns that encourage and place significance on these actions and citizen involvement. This echoes the data from Herezniak and Florek's (2018) study in which the participant from Milan noted "You have to create the idea that success depends on the behaviour of citizens of all levels (policemen, salespeople etc.). You have to inject that attitude from the very beginning" (p. 96). Messages that encourage citizens to take pride in the event and represent their country, or embrace their role as an ambassador during the event may also help build national pride (patriotism) and a sense of engagement among the citizenry. This could be done through specific initiatives with educational institutions, as was partially implemented with the "School Project" during the Expo Milan. It should also involve social media platforms given their penetration around the globe, the scalability of their messages, and their function as enablers of interaction and dialog.

\section{Citizens as advocates or activists during mega-events: the role of megaphoning}

The concept of megaphoning was developed in the employee context (Kim and Rhee 2011) and has been utilized successfully in research on fan publics (Krishna and Kim 2016), as well as in the conceptualization of within-border foreign publics' communicative action in support of, or against, their host country (Vibber and Kim 2015, 2019). Its application in this study on citizens' communicative action around megaevents is the first that the authors are aware of on this topic. This represents an important step in understanding the people-to-people diplomacy potential of mega-events and how citizens are communicating with others about mega-events.

This study found a significant difference in megaphoning behavior between the groups that placed high and low importance on interacting with foreigners. Those scoring high on importance not only reported significantly lower scores on negative megaphoning but also reported significantly higher scores on positive megaphoning. Thus, citizens' perceptions of the importance of interacting with foreigners may not only be related to their perceptions of mega-events, but also their active communication about them in support of the events and/or their country.

\section{Practical implications}

Citizen perceptions of the social impacts of mega-events are important to be aware of and engage with because they can affect the viability of the event and its overall implementation (e.g., No Expo Movement or No Boston Olympics) (Chalip and Fairley 2019; Massidda and Parisi 2016). Citizens often engage in positive or negative megaphoning about their experiences and perceptions of an event and their government's handling of it in person or online, amplifying the reach of their communication. Therefore, local administrations and governments may do well to reinforce the importance of citizens acting as representatives or ambassadors during mega-events, as well as the significance of their positive interactions with foreigners to the event's success. This means not only developing effective communication strategies to engage with citizens, but also improving listening behaviors with respect to digital publics (Lovari and Parisi 2015). It is also important that the messages come from a place of collaboration with the citizens and not reflect 
tokenism or coerced participation, in order for the messages to be seen as authentic.

When developing mega-events, organizers should keep in mind that having citizens who place a high-importance on interacting with foreigners and having positive interactions during mega-events are key to the diplomacy goals of hosting these events in the first place (e.g., building positive reputation, tourism and travel intention, etc.). Tam and Kim's (2019) recent taxonomy of important foreign publics for achieving public diplomacy goals highlights that a positive behavioral experience with a country is key to having the foreign public communicate positively on behalf of that country (i.e., advocational or ambassadorial foreign publics). An empirical study by Vibber and Kim (2019) provides further support for this connection, finding that within-border foreign publics (e.g., international exchange students) who perceived their relationship with the host country positively reported higher scores on positive megaphoning and lower scores on negative megaphoning. In addition, this positive or negative megaphoning to members of their home country was positively related to an echoing effect where members of their social networks in their home country repeated or reshared the original messages, positive or negative, and magnifying their reach (c.f. Vibber and Kim 2019). Given the massive influx of foreigners to a country during these events and the likelihood that they are interacting with citizens at some point, if not daily during their stay, person-to-person diplomacy has strong potential to color the foreigners' experience with, opinion of and communication about the host country. Thus, the potential role of citizen diplomacy as well as citizens' stance toward it should be better understood and considered closely in countries hosting mega-events.

\section{Considering the context: citizens' voice and perception of the government's role}

This study focused on a democratic country and society (Italy), in which citizens are more likely to assume that they have a voice which has some degree of power than those in countries without a democratic tradition (e.g., Wang 2014; Ye et al. 2012). While it was outside of the scope of this study to examine the government-citizen relationship, work by Kim and Krishna (2018) found that citizens' perceptions of government communication, both in terms of approach (e.g., bridging or buffering) and authenticity were related to their positive and negative megaphoning behaviors about the government. These findings highlight the practical importance of public sector organizations and governments positively and proactively engaging with citizens when taking on mega-events. This is echoed in the Official Expo Milan Report which emphasized the relevance of citizens' engagement as a key leverage point in the success of Expo Milan
(Expo 2015 Spa, 2018). It can also be seen in the IOC's recently issued recommendation that governments hold a referendum to show citizen support before placing an Olympic bid (Wharton, 2019).

\section{Limitations and future studies}

As an exploratory study examining citizens' perceptions of and perceived role in hosting mega-events, this research is not without limitations. First, online surveys rely on a selfselecting, non-probabilistic sample (Vehovar and Manfreda 2008). Second, it is possible that the social media-based recruitment procedure resulted in a sample with a higher inclination to communicative action, since it is not likely the so-called lurkers (inactive online users) would choose to participate. However, it is unlikely that the participants' inclination would skew only toward positive communication, as social media sites, are often also full of disapproving publics. Despite these limitations, the authors believe this research succeeded in providing useful insights for this underexplored area, which should be further developed in future studies and the forthcoming Dubai World Exhibition, rescheduled for 2021, even if the context could be significantly influenced by the COVID-19 pandemic. Future studies should also examine the role of citizen publics in mega-events in varied countries, cultures, and political as well as financial contexts to gain a better understanding of the nuanced implications of these contextual factors. Finally, although this study sought to address the gap in understanding around citizens' perceptions of and role in mega-events, it was not within the scope of the study to fully explore their perceived relationship with their government and the role of that communication in the life cycle of the event. Future work should attempt to take a more holistic approach to examining citizen engagement and the government-citizen relationship throughout the life cycle of a mega-event.

\section{Declarations}

Conflict of interest On behalf of all authors, the corresponding author states that there is no conflict of interest.

\section{References}

Anholt, S. 2007. Competitive Identity: The New Brand Management for Nations, Cities and Regions. London: Palgrave Macmillan.

Anholt, S. 2015. Public diplomacy and competitive identity: Where's the link? In International public relations and public diplomacy, ed. G. Golan, S.U. Yang, and D.F. Kinsey, 189-208. New York: Peter Lang.

Attias, S. 2012. Israel's new peer-to-peer diplomacy. The Hague Journal of Diplomacy 7: 473-482. 
Billings, A.C., and M.C. Hardin. 2013. Megasport in a mega-city to a mega-audience: The impact of 2012 London Olympic Media. Mass Communication and Society 16: 847-849.

Braun, E., M. Kavaratzis, and S. Zenker. 2013. My city-My brand: The different roles of residents in place branding. Journal of Place Management and Development 6 (1): 18-28.

Bravo, V. 2015. The importance of diaspora communities as key publics for national governments around the world. In International public relations and public diplomacy, ed. G. Golan, S.-U. Yang, and D.F. Kinsey, 279-296. New York: Peter Lang.

Casais, B., and P. Monteiro. 2019. Residents' involvement in city brand co-creation and their perceptions of city brand identity: A case study in Porto. Place Branding and Public Diplomacy 15: 229237. https://doi.org/10.1057/s41254-019-00132-8.

Chalip, L., and S. Fairley. 2019. Thinking strategically about sport events. Journal of Sport \& Tourism 23 (4): 155-158.

Deng, Y., S.W. Poon, and E.H.W. Chan. 2016. Planning mega-event built legacies-A case of Expo 2010. Habitat International 53: 163-177.

Dubinsky, Y. 2019. From soft power to sports diplomacy: A theoretical and conceptual discussion. Place Branding and Public Diplomacy 15: $156-164$

Expo 2015 Spa. 2018. Expo Milano 2015. Report Ufficiale. La sfida dell'Italia per un'esposizione universale innovativa. http://www. expo2015.org/2018/06/07/expo-milano-2015-pubblica-il-suoreport-ufficiale/. Accessed 23 July 19.

Grix, J., and B. Houlihan. 2014. Sports mega-events as part of a nation's soft power strategy: The cases of Germany (2006) and the UK (2012). The British Journal of Politics and International Relations 16: 572-596.

Herezniack, M., and M. Florek. 2018. Citizen involvement, place branding and mega events: Insights from Expo host cities. Place Branding and Public Diplomacy 14: 89-100.

Heslop, A.L., J. Nadeau, and N. O'Reilly. 2009. China and the Olympics: Views of insiders and outsiders. International Marketing Review 27 (4): 404-433.

Kim, J., J.H. Kang, and Y.-K. Kim. 2014. Impact of mega sport events on destination image and country image. Sport Marketing Quarterly 23: 161-175.

Kim, J.-N., and Y. Rhee. 2011. Strategic thinking about employee communication behavior (ECB) in public relations: Testing the models of megaphoning and scouting effects in Korea. Journal of Public Relations Research 23: 243-268.

Kim, S., and A. Krishna. 2018. Unpacking public sentiment toward government: How government communication strategies affect public engagement, cynicism, and word of mouth behavior. International Journal of Strategic Communication 12 (3): 215-236.

Krishna, A., and S. Kim. 2016. Bridging strategy to understand fan publics' positive communicative actions. In Public relations and participatory culture: Fandom, social media and community engagement, ed. A. Hutchins and N.T.J. Tindall, 22-32. New York, NY: Routledge.

Koba, M. 2014. World Cup by the numbers: Most expensive ever! CNN, 13 June. https://www.cnbc.com/2014/06/11/conomics-bythe-numbers.html. Accessed 30 Mar 2019.

Lamberti, L., G. Noci, J. Guo, and S. Zhu. 2011. Mega-events as drivers of community participation in developing countries: The case of Shanghai World Expo. Tourism Management 32: 1474-1483.

Lovari, A., and L. Parisi. 2015. Listening to digital publics. Investigating citizens' voice and engagement within Italian Municipalities' Facebook Pages. Public Relations Review 41: 205-213.

Massidda, L., and S. Parisi. 2016. TOO BIG, WILL FAIL Megaevents and Protest Participation. Partecipazione e Conflitto, The Open Journal of Sociopolitical Studies 9 (3): 949-980.

Massidda, L., and S. Parisi. 2017. (Don't) reclaim the media. 'Attitudine no expo' network, urban conflict and media practices. In
Net-activism. How digital technologies have been changing individual and collective actions, ed. F. Antonelli, 109-115. Rome: Roma 3 Press.

Melissen, J. 2005. The new public diplomacy: Soft power in international relations. New York, NY: Palgrave Macmillan.

Muller, M. 2015. What makes an event a mega-event? Definitions and sizes. Leisure Studies 34 (6): 627-642.

Murray, S., and A.G. Pigman. 2014. Mapping the relationship between international sport and diplomacy. Sport in Society 17 (9): 1098-1118.

Nye, J.S. 2004. Soft power: The means to success in world politics. New York, NY: PublicAffairs.

Nye, J.S. 2008a. Security and smart power. American Behavioral Scientist 51 (9): 1351-1356.

Nye, J.S. 2008b. Foreward. In Soft power superpowers: Cultural and national assets of Japan and the United States, ed. W. Yasushi and D.L. McConnell. London: Sharpe.

Nye, J.S. 2011. The future of power. New York, NY: PublicAffairs.

Pappas, N. 2014. Hosting mega events: Londoners' support of the 2012 Olympics. Journal of Hospitality and Tourism Management 21: 10-17.

Parodi, E. 2014. Arrests, corruption probe, cast cloud over Italy's Expo 2015. Reuters, 12 May. https://www.reuters.com/artic le/us-italy-corruption-expo-idUSBREA4B0FW20140512. Accessed 30 Mar 2019.

Payne, J.G. 2009. Trends in global public relations and grassroots diplomacy. American Behavioral Scientist 53 (4): 487-492.

Preuss, H., and H.A. Solberg. 2006. Attracting major sporting events -The role of local residents. European Sport Management Quarterly 6 (4): 391-411.

Ritchie, B.W., R. Shipway, and B. Cleeve. 2009. Resident perceptions of mega-sporting events: A non-host city perspective of the 2012 London Olympic Games. Journal of Sport and Tourism 14 (2-3): 143-167.

Tam, L., and J.-N. Kim. 2019. Who are the publics in public diplomacy? Proposing a taxonomy of foreign publics as an intersection between symbolic environment and behavioral experiences. Place Branding and Public Diplomacy 15: 28-37.

Vehovar, V., and K.L. Manfreda. 2008. Overview: Online surveys. In The SAGE handbook of online research method, ed. N. Fielding, R.M. Lee, and G. Blank. London: SAGE/The Brookings Institutions.

Vibber, K., and J.-N. Kim. 2015. Diplomacy in a globalized world: Focusing internally to build relationships externally. In International public relations and public diplomacy, ed. G. Golan, S.U. Yang, and D.F. Kinsey, 131-145. New York: Peter Lang.

Vibber, K., and J.-N. Kim. 2019. Advocates or adversaries? Explicating within-border foreign publics' role in shaping soft power through megaphoning and echoing. Place Branding and Public Diplomacy. https://doi.org/10.1057/s41254-019-00156-0.

Wang, J. 2013. Shaping China's global imagination: Branding nations at the World Expo. New York, NY: Palgrave Macmillan.

Wang, P. 2014. Government intervention and the empowerment process: Citizen involvement in the 2010 Shanghai World Expo. Journal of Public Affairs 14 (2): 130-141.

Wharton, D. 2019. Olympics, in future, will test local support before awarding Games, The LA Times, 26 June. https://www.latimes. com/sports/la-sp-olympics-la2028-host-city-rules-20190626story.html. Accessed 24 July 2019.

Ye, X., N. Scott, P. Ding, and Y. Huang. 2012. Residents' attitudes toward the 2010 World Expo in Shanghai prior to and during the event. Journal of Sustainable Tourism 20 (8): 1087-1105.

Yun, S.H. 2012. Relational public diplomacy: The perspective of sociological globalism. International Journal of Communication 6: 2199-2219. 
Yun, S., and E. Toth. 2009. Future sociological public diplomacy and the role of public relations: Evaluation of public diplomacy. American Behavioral Scientist 53 (4): 493-503.

Yun, S., and K. Vibber. 2012. The strategic values and communicative actions of Chinese students for Korean sociological diplomacy. International Journal of Strategic Communication 6 (1): 77-92.

Zaharna, R. S. 2005. The network paradigm of strategic public diplomacy. Foreign Policy in Focus Policy Brief, 10 (1). http://www. fpif.org/briefs/vol10/v10n01 pubdip.html

Zhou, S., B. Shen, C. Zhang, and X. Zhong. 2013. Creating a competitive identity: Public diplomacy in the London Olympics and media portrayal. Mass Communication and Society 16 (6): 869-887.

Publisher's Note Springer Nature remains neutral with regard to jurisdictional claims in published maps and institutional affiliations.

Kelly Vibber Dr. Vibber's research focuses largely on the intersections between public relations and public diplomacy, the role of withinborder foreign publics, and the impact of internal relations on external relationships. In addition, she has done related work on nation and place branding, relationship building and management between entities and publics, as well as peace building. Her work has been presented at and published in the national and international conferences and journals.

Alessandro Lovari Dr. Lovari's main research interests are public communication, public relations, and the relationships between public administrations, mass media, and citizens, in particular focusing on the role of social media and digital technologies. He also studies the characteristics of Web 2.0 and social media and their impact on health organizations, companies and citizens' behaviors and communicative practices. His works have been published in 10 books and in national and international journals such as Public Relations Review, Health Communication, Prism, and International Journal of Strategic Communication. 